(c) American Dairy Science Association, 2003.

\title{
Growth Hormone and Milking Frequency Act Differently on Goat Mammary Gland in Late Lactation
}

\author{
M. Boutinaud, ${ }^{*, 1}$ C. Rousseau, ${ }^{*}$ D. H. Keisler, $\dagger$ and H. Jammes* \\ *Biologie Cellulaire et Moléculaire, INRA, 78352 Jouy en Josas Cedex, France \\ †Animal Sciences Unit, University of Missouri, Columbia 65211-5300
}

\begin{abstract}
In ruminants, milk yield can be affected by treatment with growth hormone (rbGH) and/or changes in frequency of milking. Frequent milkings encourage the maintenance of lactation, whereas infrequent milkings result in mammary involution. Our objective was to evaluate the influence of rbGH treatment and milking frequency on mammary gland morphology and milk composition. After adaptation to twice-daily milkings, six Saanen goats in late lactation were milked once daily from one udder-half and thrice-daily from the other udder-half. Concurrently, three of the six goats received daily injections of rbGH. After $23 \mathrm{~d}$ of treatment, milking frequency significantly affected milk yield ( $+8 \%$ vs. $-26 \%$ for thrice- vs. once-daily milking). Additionally, treatments of rbGH increased milk yield from thrice-daily milked udder-halves $(+19 \%)$, but failed to abate the reduction in milk yield from once-daily milked udderhalves $(-31 \%)$. Mammary glands were heavier in the frequently milked udder-halves and in GH-treated goats. Based on histological and DNA analysis of mammary tissues, it was determined that milking frequency clearly affected epithelial cell numbers and alveolar diameter, whereas rbGH induced a potential cell hypertrophy and only a tendency to increase and/or maintain the mammary cell number. RNA concentration and kappa casein gene expression were not affected by treatments. In udder-halves milked once-daily, low casein:whey protein ratios, high $\mathrm{Na}^{+}: \mathrm{K}^{+}$ratios, and high somatic cell counts (SCC) were indicative of changes in epithelial permeability, which rbGH treatment facilitated. The present data suggest that milking frequency and exogenous treatments of rbGH use different cellular mechanisms to influence mammary gland morphology and milk production.
\end{abstract}

(Key words: growth hormone, milking frequency, milk yield, mammary gland)

Received April 24, 2002.

Accepted September 10, 2002.

Corresponding author: M. Boutinaud; e-mail: boutinau@jouy, inra.fr.

${ }^{1}$ Current address: UMRPL, INRA, 35590 Saint Gilles, France.
Abbreviation key: FITC = fluorescein isothiocyanate, $\mathbf{G H}=$ growth hormone, $\mathbf{S S C}=$ sodium saline citrate.

\section{INTRODUCTION}

Milk yield can be affected by milking frequency and/ or growth hormone (GH) treatment. Milking goats thricedaily instead of twice-daily increases milk yields by 10 to $20 \%$ (Amos et al., 1985; Knight, 1992; Campos et al., 1994), whereas once daily milking has been reported to decrease milk yields by 10 to $30 \%$ (Wilde and Knight 1987; Carruthers et al., 1991; Lynch et al., 1991). The immediate effect of thrice-daily milking on mammary tissues is an increase in cellular differentiation followed by proliferation of secretory cells (Knight et al., 1990). In contrast, after $4 \mathrm{wk}$ of milking lactating goats once daily, smaller alveoli and a loss of mammary cells due to programmed cell death by apoptosis was reported ( $\mathrm{Li}$ et al., 1999). Alternatively, treatments with GH are known to increase milk yield by 5 to $30 \%$ in goats (Mepham et al., 1984; Nielsen et al., 1988; Disenhaus et al., 1995), but the underlying mechanisms by which this occurs is unknown. Frequent milkings combined with GH treatment lead to a significant stimulation in milk production and improve lactation persistency by maintaining the number of secretory cells (Knight et al., 1990). Some evidence exists to support the hypothesis that the mechanisms by which treatments of GH vs. milking frequency increase milk yield differ. In association with infrequent milking, treatments of GH were able to increase milk yield in cows and thus compensate for the loss of milk yield induced by once-daily milking (Carruthers et al., 1991; Stelwagen et al., 1994a). This compensatory effect could be due to better maintenance of the number of secretory cells by a survival effect associated with treatments of $\mathrm{GH}$ or due to the stimulation of cell proliferation, but this hypothesis is yet to be tested in the goat.

Herein, we report the results obtained from an experiment conducted in lactating goats, whereby the effects of milking frequency and GH treatment were used to evaluate differential adaptation by mammary cells during milk production stimulation and the possible compensatory effect of GH during an inhibition. The objectives 
of our investigation were to: 1) evaluate the regulation of milk production and milk composition, and 2) evaluate the number of mammary cells, the secretory activity of mammary cells, and mammary epithelium integrity.

\section{MATERIALS AND METHODS}

\section{Animals and Experimental Design}

Saanen goats, free from clinical mastitis, were bred at the INRA experimental farm of Brouëssy (France) and fed according to INRA recommendations. Six nonpregnant goats of about $60 \mathrm{~kg}$ live weight, in their 32nd week of lactation with similar milk yields were selected for use. Animals were also chosen with the most similar milk yield for the two udder-halves as possible. During 2 wk before treatments, both udder-halves were milked twice daily at 0700 and $1900 \mathrm{~h}$. Thereafter, the right udder-half of each goat was milked thrice daily at 0700 , 1300 , and $1900 \mathrm{~h}$, and the left udder-half was milked at $0700 \mathrm{~h}$ only for $23 \mathrm{~d}$. The milk yield from each udder-half was recorded at each milking. Goats were concurrently divided into two groups: control (no injection) vs. treatment with $5 \mathrm{mg}$ of recombinant GH (recombinant bovine GH, rbGH; Somidobove, Elanco, Indianapolis, IN) given subcutaneously once daily after the morning milking for $23 \mathrm{~d}$. At d 24, goats were slaughtered by exsanguination after electronarcosis just after the last morning milking. Procedures relating to the care and use of animals were approved by the French Ministry of Agriculture according to French regulations (guideline 12/12/1997). After slaughter, the udder was removed, trimmed of extraparenchymal tissue (skin, teat, subcutaneous fat), and separated into right and left halves. Each udder half was weighed and five parenchyma samples were collected. The mammary samples were rapidly frozen in liquid nitrogen, and stored at $-20^{\circ} \mathrm{C}$ until RNA preparation or prepared for immunohistochemical analysis.

\section{Immunohistochemical Analysis}

Mammary gland tissue samples were fixed in $4 \%$ paraformaldehyde-PBS for $24 \mathrm{~h}$ at $4^{\circ} \mathrm{C}$, cryo-protected in $20 \%$ sucrose for $48 \mathrm{~h}$ at $4^{\circ} \mathrm{C}$, frozen at $-45^{\circ} \mathrm{C}$ in an isopentane bath cooled on dry ice, and stored at $-80^{\circ} \mathrm{C}$ until use. Ten micrometer-thick cryosections (20 sections for each parenchyma samples) were mounted onto Superfrost/ Plus slides (Prolabo, Bondoufle, France). For each udder half, three different mammary gland sections were analyzed. The tissue sections were permeabilized in PBS with $0.05 \%$ saponin, $2 \%$ BSA, $0.05 \%$ sodium azide for 1 $\mathrm{h}$ at room temperature. Tissues were then incubated in the presence or absence of a primary antibody in the same buffer for $1 \mathrm{~h}$ at room temperature. After three washings with $0.2 \%$ BSA-PBS, $0.05 \%$ saponin, $0.05 \%$ sodium azide, sections were incubated in the presence of a second fluorescein isothiocyanate (FITC)-conjugated antibody for $1 \mathrm{~h}$ at room temperature. After $10 \mathrm{~min}$ of washing, mammary gland sections were counterstained for $15 \mathrm{~min}$ with $20 \mu \mathrm{g} / \mathrm{ml}$ Hoechst (3342; Sigma). Subsequently, the slides were mounted with Vectashield (Valbiotech, Paris, France) and analyzed by fluorescence microscopy.

Antibodies. The antibodies used for staining mammary tissue sections were: 1) a monoclonal antibody directed against caprine $\alpha \mathrm{S} 1$ casein obtained from M.-F. Mahé (INRA, Jouy en Josas, France), 2) a monoclonal antibody directed against alpha smooth muscle actin (A 2547 Sigma), and 3) a polyclonal FITC-conjugated antimouse IgG antibody (Immunotech, Marseille, France).

The $\alpha \mathrm{S} 1$ casein positive cells were considered as epithelial cells. On photographs of mammary gland slides, the epithelial cells showing Hoechst positive nucleus were counted in order to obtain the number of epithelial cells per alveolus. The alveolar diameter was measured on photographs for each mammary gland slide and adjusted with the magnification (on average $0.22 \mathrm{~mm}^{2}$ in duplicate determinations).

\section{DNA Concentration and Total DNA}

DNA extractions were performed using $1 \mathrm{~g}$ of mammary tissue homogenized in ice-cold water. Homogenates were lysed in a solution containing $5 \mathrm{~m} M$ Tris-HCl, $\mathrm{pH}$ 8, $5 \mathrm{~m} M$ EDTA, $0.3 M$ sodium acetate, $1 \%$ SDS added with proteinase K (Roche Diagnostics, Meylan, France) at a final concentration of $0.5 \mathrm{mg} / \mathrm{ml}$ during $50 \mathrm{~min}$ at $50^{\circ} \mathrm{C}$. After phenol-chloroform extraction followed by chloroform extraction, DNA concentration was measured by a fluorometric method using DNA as standard samples (Labarca and Paigen, 1980). DNA concentration was multiplied by the weight of the mammary gland to provide an estimate of the total DNA content.

\section{Total RNA Preparation}

Total RNA was extracted according to a previous report (Puissant and Houdebine, 1990). Briefly, $1 \mathrm{~g}$ of mammary tissue was homogenized at $4^{\circ} \mathrm{C}$ in a $4 M$ guanidinium thiocyanate solution containing $25 \mathrm{~m} M$ sodium citrate, $\mathrm{pH} \mathrm{7,} \mathrm{0.5 \%} N$-lauryl sarkosyl, and $100 \mathrm{~m} M$ mercaptoethanol $(1 \mathrm{~g} / 10 \mathrm{ml}$ of solution). Homogenates were then acidified using $1 \mathrm{ml}$ of $2 M$ sodium acetate, $\mathrm{pH}$ 5.2. Ten milliliters of Tris-EDTA saturated phenol (100 $\mathrm{m} M$ Tris-HCl, $\mathrm{pH} 7.5,10 \mathrm{~m} M$ EDTA), and $2 \mathrm{ml}$ of isoamylic alcoholchloroform (1:49) were added successively to the homogenates. After $15 \mathrm{~min}$ of incubation at $4^{\circ} \mathrm{C}$, the mixture was centrifuged $\left(5,000 \times g, 10^{\circ} \mathrm{C}, 20 \mathrm{~min}\right)$. The upper phase was separated and one volume of isopropanol was 
added to precipitate RNA overnight at $-20^{\circ} \mathrm{C}$. The RNA pellet was recovered by centrifugation $(5000 \times g, 20 \mathrm{~min}$, $4^{\circ} \mathrm{C}$ ), rinsed with $70 \%$ ethanol, and dissolved in sterile water. After one additional extraction by isoamylic alcohol-chloroform ( $\mathrm{vol} / \mathrm{vol}$ ), the aqueous phase was precipitated in the presence of $300 \mathrm{~m} M$ sodium acetate and 2.5 volumes of ethanol. RNA was stored in this precipitated form at $-20^{\circ} \mathrm{C}$ until quantification by optical density measurements, RNA concentration determination, and analysis by Northern blot.

\section{Northern Blot Analysis}

Briefly, $10 \mu \mathrm{g}$ of formamide-formaldehyde denatured total RNA were size-separated by electrophoresis on a $1.5 \%$ agarose gel in $2.2 \mathrm{M}$ formaldehyde in $10 \mathrm{~m} M$ sodium phosphate buffer, $\mathrm{pH}$ 7.5. RNA were transferred to Zeta Probe (Biorad, Marnes La Coquette, France) by capillary blotting at high ionic strength $(10 \times$ sodium saline citrate (SSC): $1.5 M$ sodium chloride, $0.15 M$ sodium citrate, $0.5 \%$ SDS). After UV fixation, the membranes were prehybridized at $65^{\circ} \mathrm{C}$ for $2 \mathrm{~h}$ in a medium containing 0.5 $M$ sodium dihydrogenphosphate, $\mathrm{pH} 7.2$, 7\% SDS, $1 \mathrm{~m} M$ EDTA and $0.5 \%$ nonfat dry milk. Hybridization was performed overnight at $65^{\circ} \mathrm{C}$ in the presence of the ${ }^{32} \mathrm{P}$ random primed probe $\left(2.10^{6} \mathrm{cpm} / \mathrm{ml}\right)$ in the same medium. Membranes were washed under high stringency conditions with $4 \times \mathrm{SSC}$ and $0.1 \% \mathrm{SDS}$ at $65^{\circ} \mathrm{C}$ for $10 \mathrm{~min}$. Autoradiographs were obtained using Amersham Hyperfilm with two amplification screens, at $-80^{\circ} \mathrm{C}$. The hybridization signals were obtained by scanning with a Storm860 scanner (Molecular Dynamics, Bondoufle, France) and quantified with Image QuaNT software (IQNT-130; Molecular Dynamics). Values were corrected using the 18S hybridization signal as a control for RNA loading.

Probes. The cDNA fragment was labeled with $\alpha\left[{ }^{32} \mathrm{P}\right]-$ dCTP (3000 Ci/mmol; ICN, Orsay, France) to a specific activity of $10^{8} \mathrm{cpm} / \mu \mathrm{g}$ of DNA using a random priming kit (Roche Mannheim, Meylan, France). A 500-bp cDNA corresponded to the 3 '-sequence of the kappa casein (kindly provided by C. Leroux). The $18 \mathrm{~S}$ cDNA encodes the full-length translated sequence (Raynal et al., 1984).

\section{Milk Yield and Composition}

Milk yield was assessed each day and twice each week milk samples were analyzed to determine milk composition. Somatic cell count was measured by Uriane Laboratory (La Capelle, France) using an automatic cell counter (Fossomatic 5,000, Foss Electrique, France). Fat and protein contents were determined using an infra-red milk analyzer (Milkoscan 4,000, Foss Electrique). Sodium and potassium concentrations were measured by flame photometry. $\mathrm{A} \mathrm{Na}^{+}: \mathrm{K}^{+}$ratio was calculated and used as indi- cator of tight junction opening. The content of noncasein nitrogen was determined in milk by a standard microKjeldahl analysis after the precipitation of casein by acid. Casein concentrations were calculated by subtraction between protein content and whey protein content determined using noncasein nitrogen content.

\section{Statistical Analysis}

Linear regressions were used to determine the relationships between milk yield and mammary gland weight and total DNA content. Correlations were determined between milk yield and DNA concentration and between protein content and whey protein content in both groups of animals. Data were analyzed by the method of least squares ANOVA (Oman and Seiden, 1988) using the general linear model procedures in the epsilon Windows software (L. Delaby, UMR-PL INRA, France). The statistical model (split-plot linear model) used to analyze the data in Tables 1 and 2 was:

$$
\mathrm{Y}_{\mathrm{ijk}}=\mu+\mathrm{M}_{\mathrm{i}}+\mathrm{G}_{\mathrm{j}}+\mathrm{A}\left(\mathrm{G}_{\mathrm{j}}\right)_{\mathrm{k}}+(\mathrm{MG})_{\mathrm{ij}}+\mathrm{e}_{\mathrm{ijk}}
$$

where $\mu=$ the overall mean, $\mathbf{M}_{\mathrm{i}}=$ the effect of the milking frequency $i, G_{j}=$ the effect of the $G H$ treatment $j, A\left(G_{j}\right)_{k}$ = the effect of the $\mathrm{GH}$ treatment within the animal $\mathrm{k}$, $(\mathrm{MG})_{\mathrm{ij}}=$ the effect of the interaction between milking frequency and GH treatment and $\mathrm{e}_{\mathrm{ijk}}=$ the error term. Considering the split-plot linear model, $M$ and $M G$ were tested against e, while $G$ was tested with $A(G)$ as an error term.

The model used to analyze the data in Tables 3 and 4 was:

$$
\begin{gathered}
\mathrm{Y}_{\mathrm{ijk}}=\mu+\mathrm{M}_{\mathrm{i}}+\mathrm{G}_{\mathrm{j}}+\mathrm{A}\left(\mathrm{G}_{\mathrm{j}}\right)_{\mathrm{k}}+\mathrm{D}_{\mathrm{l}}+(\mathrm{MG})_{\mathrm{ij}}+\left(\mathrm{MA}\left(\mathrm{G}_{\mathrm{j}}\right)\right)_{\mathrm{ik}} \\
+(\mathrm{GD})_{\mathrm{jl}}+(\mathrm{MD})_{\mathrm{il}}+\left(\mathrm{A}\left(\mathrm{G}_{\mathrm{j}}\right) \mathrm{D}\right)_{\mathrm{kl}}+(\mathrm{MGD})_{\mathrm{ijl}}+\mathrm{e}_{\mathrm{ijk}},
\end{gathered}
$$

where $\mu$ = the overall mean, $\mathrm{M}_{\mathrm{i}}$ = the effect of the milking frequency $i, G_{j}=$ the effect of the $G H$ treatment $j, A\left(G_{j}\right)_{k}$ $=$ the effect of the GH treatment within the animal $\mathrm{k}, \mathrm{D}_{\mathrm{l}}$ $=$ the effect of the day, $(\mathrm{MG})_{\mathrm{ij}}=$ the interaction between milking frequency and $\mathrm{GH}$ treatment, $\left(\mathrm{MA}\left(\mathrm{G}_{\mathrm{j}}\right)\right)_{\mathrm{ik}}=$ the interaction between milking frequency and $\mathrm{GH}$ treatment with the animal, $(\mathrm{GD})_{\mathrm{jl}}=$ the interaction between GH treatment and the day, $(\mathrm{MD})_{\mathrm{il}}=$ the interaction between milking frequency and the day, $\left(A\left(G_{j}\right) D\right)_{k l}=$ the interaction between $\mathrm{GH}$ treatment within animal and the day, $(\mathrm{MGD})_{\mathrm{ij} 1}=$ the interaction between milking frequency, GH treatment and the day, and $\mathrm{e}_{\mathrm{ijkl}}=$ the error term. Considering the split-plot linear model, $\mathrm{D}, \mathrm{MD}$, MGD was tested against e; GD was tested with $A(G) D$ as an error term; M, MG, $A(G)$ was tested with $M A(G)$ as an error term and $G$ with $A(G)$ as an error term. 
Table 1. Milk yield and mammary gland characteristics (weight, DNA, and RNA concentrations) from the udder-halves milked once (1×) vs. thrice (3×) daily in control vs. GH-treated goats after $23 \mathrm{~d}$ of treatment. Least square means \pm SEM.

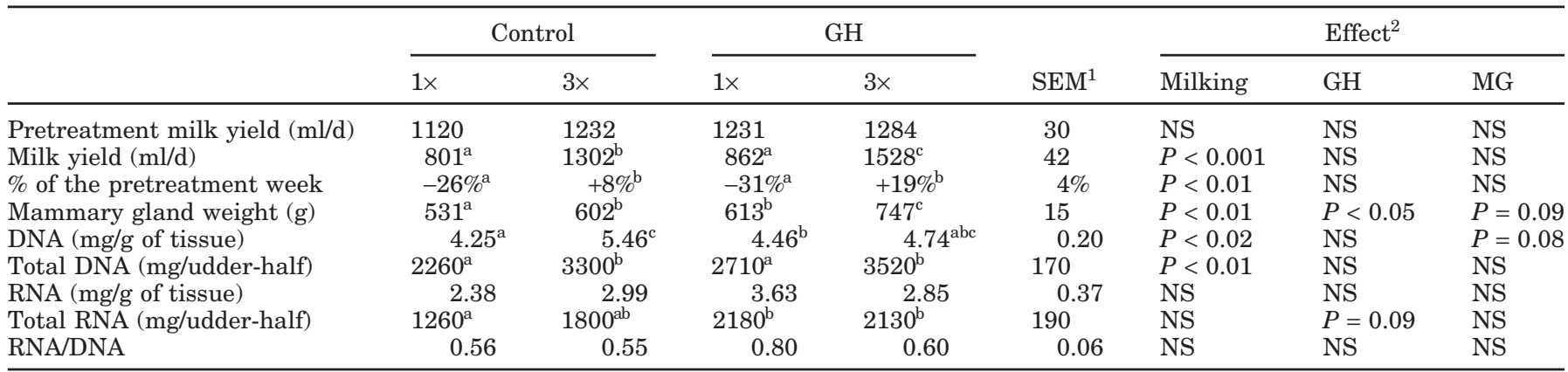

${ }^{\mathrm{a}, \mathrm{b}, \mathrm{c}}$ Within a row means without a common superscript letter $\operatorname{differ}(P<0.05)$.

${ }^{1}$ SEM: standard error of the mean.

${ }^{2}$ Analysis of variance tested for effects of milking frequency, GH treatment, goats, MG = interaction between milking frequency and GH treatment.

Differences between groups in terms of milk yield, protein content, and SCC means were assessed by Student's $t$-test: paired analysis to detect differences compared with pretreatment weeks and between udder-halves; nonpaired Student's $t$-test was performed to detect differences between GH-treated and control goats. Means were considered different if $P<0.05$.

\section{RESULTS}

\section{Milk Yield}

For all udder-halves, milk yield was consistent during the 2 wk before treatments (Table 1, Figure 1). Subsequently, milking frequency progressively and significantly affected milk yield $(P<0.001$, Table 1$)$. Udderhalves that were milked most frequently produced the most milk ( $P<0.01$, paired $t$-test), while milk yield rapidly declined in the udder-halves milked once daily $(P<$ 0.001 , paired $t$-test). After $23 \mathrm{~d}$ of differential milking frequency, milk yields were $8 \%(P<0.05$, paired $t$-test $)$ above pretreatment milk yields for udders milked thrice daily and $26 \%(P<0.01$, paired $t$-test $)$ below pretreatment milk yields for udder-halves milked once daily (Table 1 ).
The galactopoietic effect associated with rbGH treatment became evident approximately $12 \mathrm{~d}$ following the initiation of GH treatment in the udder-halves milked thrice daily $(+19 \%$ after $23 \mathrm{~d}$ of treatment, $P<0.01$, paired $t$ test). No evidence of a GH effect was observed in the udder-halves milked once daily ( $-31 \%$ after $23 \mathrm{~d}$ of treatment in percentage of the pretreatment week mean, $P<$ 0.01 , paired $t$-test).

\section{Mammary Gland Weight}

Mammary gland from udder-halves milked thrice daily was significantly heavier than those from udder-halves milked once daily $(P<0.01$, Table 1$)$. GH treatment induced higher mammary gland weights for both milking frequencies but only significantly for the udder-halves milked thrice daily. A more marked difference of mammary gland weights was found between udder halves when GH treatment was associated with frequent milking (613 vs. 531 and 747 vs. $602 \mathrm{~g}$ for once and thrice daily milkings, respectively).

A positive and significant $(P<0.05)$ linear relationship was observed between milk yield and mammary gland

Table 2. Number of epithelial cells per alveolus and alveolar diameter in the mammary gland sections from udder-halves milked once (1×) vs. thrice (3x) daily in control and GH-treated goats after $23 \mathrm{~d}$ of treatment. Least square means \pm SEM.

\begin{tabular}{|c|c|c|c|c|c|c|c|c|}
\hline & \multicolumn{2}{|c|}{ Control } & \multicolumn{2}{|c|}{ GH } & \multirow[b]{2}{*}{$\mathrm{SEM}^{1}$} & \multicolumn{3}{|c|}{ Effect $^{2}$} \\
\hline & $1 \times$ & $3 \times$ & $1 \times$ & $3 \times$ & & Milking & GH & MG \\
\hline Cell number per alveolus & $22.6^{\mathrm{a}}$ & $28.4^{\mathrm{c}}$ & $22.8^{\mathrm{a}}$ & $24.4^{\mathrm{ab}}$ & 0.5 & $P<0.001$ & NS & $P<0.02$ \\
\hline Alveolar diameter $(\mu \mathrm{m})$ & $93.6^{\mathrm{a}}$ & $108.7^{\mathrm{b}}$ & $91.9^{\mathrm{a}}$ & $104.6^{\mathrm{b}}$ & 3.0 & $P<0.02$ & NS & NS \\
\hline
\end{tabular}

${ }^{\mathrm{a}, \mathrm{b}, \mathrm{c}}$ Within a row means without a common superscript letter $\operatorname{differ}(P<0.05)$.

${ }^{1}$ SEM: standard error.

${ }^{2}$ Analysis of variance tested for the effects of milking frequency, GH treatment, goats and MG = interaction between milking frequency and GH treatment. 
Table 3. Protein and fat contents in milk from udder-halves milked once (1×) vs. thrice (3×) daily in control and GH-treated goats at d 12 and 19 of treatment. Least square means \pm SEM.

\begin{tabular}{|c|c|c|c|c|c|c|c|c|c|c|c|c|}
\hline & \multicolumn{4}{|c|}{ d 12} & \multicolumn{4}{|c|}{ d 19} & \multirow[b]{3}{*}{$\mathrm{SEM}^{1}$} & \multicolumn{3}{|c|}{ Effect $^{2}$} \\
\hline & \multicolumn{2}{|c|}{ Control } & \multicolumn{2}{|c|}{ GH } & \multicolumn{2}{|c|}{ Control } & \multicolumn{2}{|c|}{ GH } & & \multirow[b]{2}{*}{ Milking } & \multirow[b]{2}{*}{$\mathrm{GH}$} & \multirow[b]{2}{*}{ MG } \\
\hline & $1 \times$ & $3 \times$ & $1 \times$ & $3 \times$ & $1 \times$ & $3 \times$ & $1 \times$ & $3 \times$ & & & & \\
\hline Milk yield (mL/d) & $903^{\mathrm{a}}$ & $1239^{b}$ & $1036^{\mathrm{a}}$ & $1577^{\mathrm{c}}$ & $786^{\mathrm{a}}$ & $1336^{\mathrm{b}}$ & $873^{\mathrm{a}}$ & $1424^{\mathrm{c}}$ & 40 & $P<0.01$ & $\mathrm{NS}$ & $\mathrm{NS}$ \\
\hline Fat $(\mathrm{g} / \mathrm{kg})$ & $41.4^{\mathrm{b}}$ & $44.5^{\mathrm{b}}$ & $38.7^{\mathrm{a}}$ & $35.0^{\mathrm{a}}$ & 35.3 & $37.3^{\mathrm{b}}$ & 34.3 & $32.9^{\mathrm{a}}$ & 1.0 & NS & $P<0.03 \mathrm{~d} 12$ & NS \\
\hline Protein $(\mathrm{g} / \mathrm{kg})$ & $35.2^{\mathrm{b}}$ & $33.0^{\mathrm{a}}$ & $36.1^{\mathrm{c}}$ & $33.4^{\mathrm{a}}$ & $37.1^{\mathrm{b}}$ & $33.7^{\mathrm{a}}$ & $37.0^{\mathrm{b}}$ & $33.9^{\mathrm{a}}$ & 0.3 & $P<0.01$ & NS & NS \\
\hline Casein $(\mathrm{g} / \mathrm{kg})$ & $25.1^{\mathrm{b}}$ & $23.7^{\mathrm{a}}$ & $24.7^{\mathrm{b}}$ & $23.4^{\mathrm{a}}$ & $25.7^{\mathrm{b}}$ & $24.3^{\mathrm{a}}$ & $25.1^{\mathrm{b}}$ & $23.9^{\mathrm{a}}$ & 0.2 & $P<0.03$ & NS & NS \\
\hline Whey protein (g/kg) & $10.2^{\mathrm{a}}$ & $9.3^{\mathrm{a}}$ & $11.4^{\mathrm{b}}$ & $10.0^{\mathrm{a}}$ & $11.3^{\mathrm{b}}$ & $9.4^{\mathrm{a}}$ & $11.9^{\mathrm{b}}$ & $10.0^{\mathrm{a}}$ & 0.3 & $P<0.01$ & $P<0.05 \mathrm{~d} 12$ & NS \\
\hline Casein:whey protein & $2.48^{\mathrm{bc}}$ & $2.56^{\mathrm{c}}$ & $\begin{array}{r}11.4 \\
2.18^{\mathrm{a}}\end{array}$ & $2.36^{\mathrm{ab}}$ & $2.30^{\mathrm{b}}$ & $2.58^{\mathrm{c}}$ & $2.16^{\mathrm{a}}$ & $2.39^{\mathrm{bc}}$ & 0.05 & $P<0.03$ & $P<0.05 \mathrm{~d} 12$ & $P<0.01$ \\
\hline Total protein (g) & $31.9^{\mathrm{a}}$ & $41.0^{\mathrm{b}}$ & $37.5^{\mathrm{b}}$ & $52.7^{\mathrm{c}}$ & $29.1^{\mathrm{a}}$ & $45.1^{\mathrm{b}}$ & $32.4^{\mathrm{a}}$ & $51.8^{\mathrm{c}}$ & 1.0 & $P<0.01$ & $P<0.04 \mathrm{~d} 12$ & $\mathrm{NS}$ \\
\hline Total fat $(\mathrm{g})$ & $37.5^{\mathrm{a}}$ & $55.2^{\mathrm{b}}$ & $40.3^{\mathrm{a}}$ & $55.2^{\mathrm{b}}$ & $28.2^{\mathrm{a}}$ & $50.4^{\mathrm{b}}$ & $29.6^{\mathrm{a}}$ & $50.0^{\mathrm{b}}$ & 1.6 & $P<0.01$ & $\mathrm{NS}$ & NS \\
\hline
\end{tabular}

a,b,c Values within a line which do not share a common superscript were significantly different: $P<0.05$.

${ }^{1}$ SEM: standard error.

${ }^{2}$ Analysis of variance tested for effects of milking frequency, GH treatment, goats, days and their interactions.

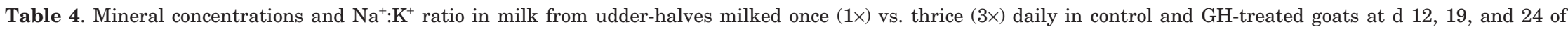
treatment. Least square means \pm SEM.

\begin{tabular}{|c|c|c|c|c|c|c|c|c|c|c|c|c|c|c|c|c|}
\hline & \multicolumn{4}{|c|}{ d 12} & \multicolumn{4}{|c|}{ d 19} & \multicolumn{4}{|c|}{$\mathrm{d} 24$} & \multirow[b]{3}{*}{$\mathrm{SEM}^{1}$} & \multirow{2}{*}{\multicolumn{3}{|c|}{ Effect $^{2}$}} \\
\hline & \multicolumn{2}{|c|}{ Control } & \multicolumn{2}{|c|}{ GH } & \multicolumn{2}{|c|}{ Control } & \multicolumn{2}{|c|}{ GH } & \multicolumn{2}{|c|}{ Control } & \multicolumn{2}{|c|}{$\mathrm{GH}$} & & & & \\
\hline & $1 \times$ & $3 \times$ & $1 \times$ & $3 \times$ & $1 \times$ & $3 \times$ & $1 \times$ & $3 \times$ & $1 \times$ & $3 \times$ & $1 \times$ & $3 \times$ & & Milking & $\mathrm{GH}$ & MG \\
\hline $\mathrm{Na}^{+}(\mathrm{mmol} / \mathrm{L})$ & $15.9^{\mathrm{a}}$ & $16.5^{\mathrm{a}}$ & $19.3^{b}$ & $17.0^{\mathrm{ab}}$ & $18.1^{\mathrm{bc}}$ & $16.3^{\mathrm{ab}}$ & $19.3^{\mathrm{c}}$ & $14.2^{\mathrm{a}}$ & $16.2^{\mathrm{ab}}$ & $14.1^{\mathrm{a}}$ & $18.4^{\mathrm{b}}$ & $15.7^{\mathrm{ab}}$ & 1.0 & $\begin{array}{l}P<0.02 \text { d } 19 \\
P<0.05 \text { d } 24\end{array}$ & $\mathrm{NS}$ & NS \\
\hline $\mathrm{K}^{+}(\mathrm{mmol} / \mathrm{L})$ & 46.9 & 45.7 & 51.0 & 50.4 & 52.5 & 50.0 & 46.8 & 50.5 & 50.7 & 50.7 & 46.4 & 50.4 & 2.3 & NS & NS & NS \\
\hline $\mathrm{Na}^{+}: \mathrm{K}^{+}$ & 0.35 & 0.36 & 0.38 & 0.34 & $0.35^{\mathrm{b}}$ & $0.33^{\mathrm{ab}}$ & $0.42^{\mathrm{c}}$ & $0.28^{\mathrm{a}}$ & $0.32^{\mathrm{a}}$ & $0.28^{\mathrm{a}}$ & $0.39^{b}$ & $0.31^{\mathrm{a}}$ & 0.02 & $\begin{array}{l}P<0.02 \text { d } 19 \\
P<0.05 \text { d } 24\end{array}$ & NS & NS \\
\hline
\end{tabular}

a,b,c Values within a line which do not share a common superscript were significantly different: $P<0.05$.

${ }^{1}$ SEM: Standard error.

${ }^{2}$ Analysis of variance tested for effects of milking frequency, GH treatment, goats, days and their interactions. 


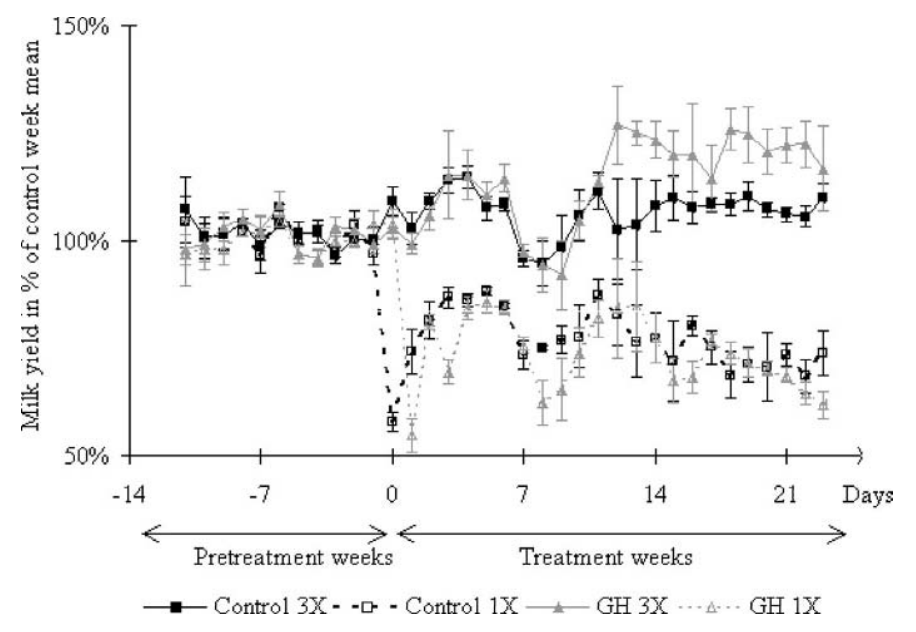

Figure 1. Milk yield of udder-halves milked once $(1 \times)$ vs. thrice (3x) daily in control vs. GH-treated goats during pretreatment weeks and $23 \mathrm{~d}$ of treatment. Mean values were expressed as a percentage of pretreatment week yield \pm SEM.

weight (Figure 2a). Linear regression slopes were similar for the control and GH treated groups, but the y-intercept was different. Clearly, GH modified the relationship between mammary weight and milk yield. Even though milk yield and mammary tissue weight were higher in GH treated goats, the milk synthesis per unit of mammary gland weight was lower in GH-treated goats than in control goats.

\section{DNA Concentration and Total DNA Content}

The udder-halves milked thrice daily had a significantly higher DNA concentration than the udder-halves milked once daily $(P<0.02$; Table 1$)$. DNA concentration was correlated with milk yield only in control goats $\left(\mathrm{R}^{2}\right.$ $=0.82, P<0.02)$. The significant effect of milking frequency on DNA concentration was not observed in GHtreated goats. GH induced a significant stimulation in DNA concentration in once-daily milked udder-halves $(P$ $<0.05)$ and a tendency to decrease DNA concentration in thrice-daily milked udder-halves $(P=0.06)$. Total DNA content was used as an indicator of the number of cells in the mammary gland. Considering the variation associated with mammary gland weight, total DNA content ( $\mathrm{g} /$ udder-half) was significantly higher $(P<0.01)$ in the udder-halves milked thrice-daily than those milked oncedaily in all goats and tended to increase in once-daily milked udder-halves on GH-treated goats compared to control goats $(P=0.10)$. A positive and significant $(P<$ 0.001) linear relationship was observed between milk yield and total mammary DNA content (Figure $2 b$ ). For all udder-halves except for once-daily milked udders in GH-treated goats, a highly significant correlation was obtained $\left(\mathrm{R}^{2}=0.89, P<0.001\right.$, Figure $\left.2 \mathrm{~b}\right)$.

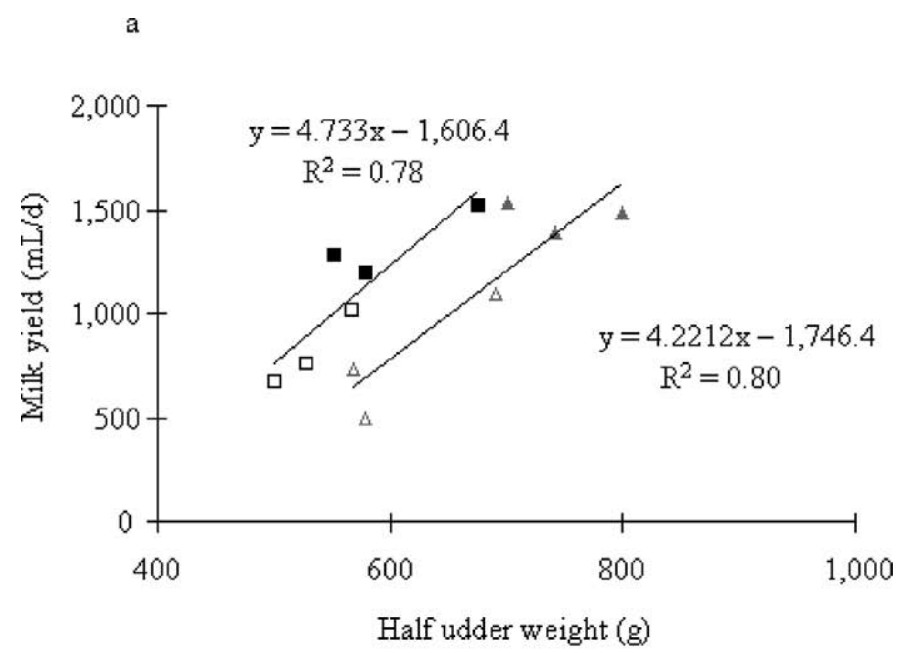

- Control 3X a Control 1X $\triangle$ GH $1 \mathrm{X}$ \& GH $3 \mathrm{X}$

b

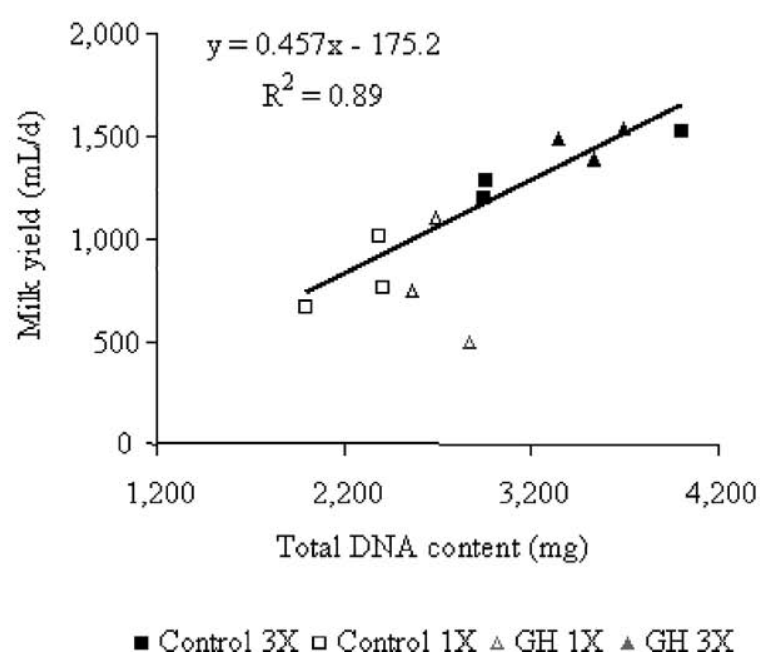

Figure 2. Relationship between milk yield and mammary gland weight (a) and between milk yield and total DNA (b) in control vs. GH-treated goats subjected to $23 \mathrm{~d}$ of differential milking frequency ( $1 \times$, once and $3 \times$, thrice daily).

\section{RNA Concentration and Total RNA Content}

RNA concentration remained relatively constant between udder-halves (Table 1). Total RNA content was used as an indicator of overall transcriptional activity. Total RNA content (g/udder-half) tended to increase with milking frequency and in GH-treated goats compared with control goats. These tendencies accounted for the differences observed between mammary gland weights. The RNA/DNA ratio was constant for all udder-halves, suggesting a similar activity per cell. 


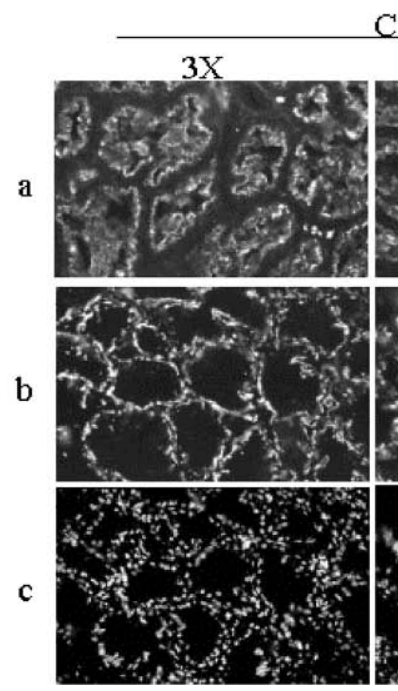

Control
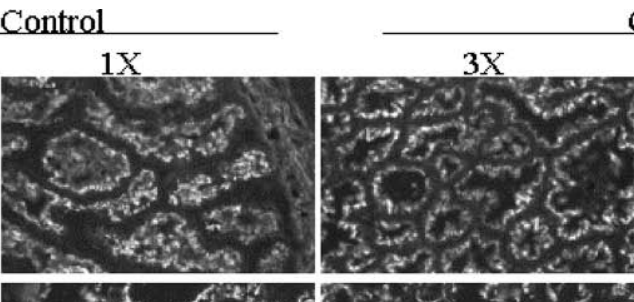

$\mathrm{GH}$
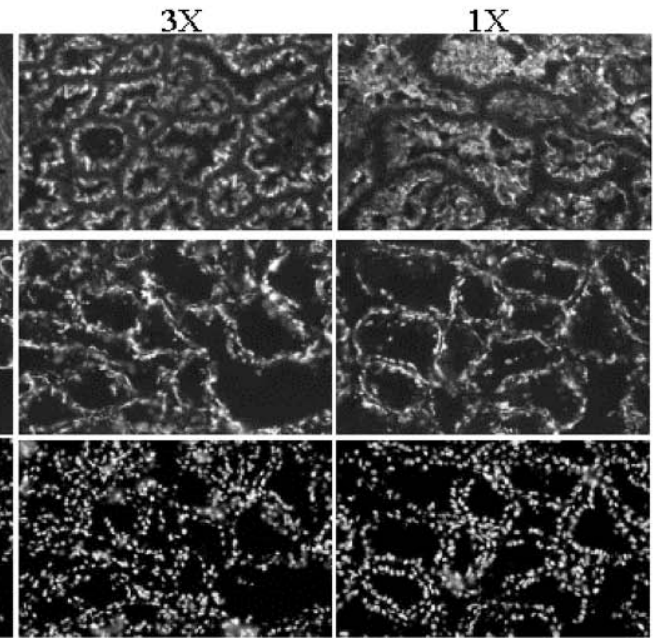

\section{夏}

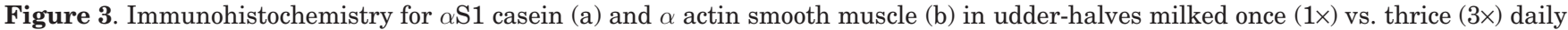
in control vs. GH-treated goats after $23 \mathrm{~d}$ of treatment. Sections of mammary gland were stained with a first monoclonal antibody and a second FITC-conjugated antibody and then counterstained with Hoechst (c), magnification $\times 64$.

\section{Mammary Gland Histology and Gene Expression}

At the end of $23 \mathrm{~d}$ of treatment, histological analyses were performed on the mammary tissues from the different groups. For immunohistochemical analysis, $\alpha$ s 1 casein and $\alpha$ smooth actin antibodies were used for specifically staining of epithelial and myoepithelial cells, respectively (Figure 3). This analysis made it possible to analyze the structure of the epithelium. Thus, no visual morphological differences of the epithelium were observed between all udder-halves. However, the number of epithelial cells per alveolus and alveolar diameter increased in relation with milking frequency (Table 2; $P<$ 0.02). No significant effect of GH was observed, except for a tendency associated with GH to inhibit the stimulation of the number of epithelial cells per alveolus induced by the increased milking frequency (Table $2 ; P<0.05$ ). The amount of kappa casein mRNA given relative to the $18 \mathrm{~S}$ mRNA was analyzed at the end of the treatment. The amount of kappa casein mRNA was not different between all udder-halves (Figure 4).

\section{Milk Composition}

To compare the synthetic capacity of udder-halves in response to GH treatment and differential milking, we analyzed several milk components. In addition, the variation in milk composition provided information on the permeability of the mammary epithelium.

Fat and protein contents. During the pretreatment interval, fat content was similar in milk from all udderhalves (on average $31.0 \pm 0.7 \mathrm{~g} / \mathrm{kg}$ ). During the treatment interval, the fat content varied but tended to increase $(P$
$=0.10)$. These variations were difficult to interpret and did not appear to be associated with the different treatments (Table 3). Throughout the treatment weeks, protein content increased $(P<0.05, t$-test $)$, first in the milk of the udder-halves milked once daily then in the udderhalves milked thrice daily in all goats (Figure 5). In spite of a significantly (Table $3 ; P<0.01$ ) higher protein content in the milk of the once-daily milked udder-halves in both groups after $12 \mathrm{~d}$ of treatment, total protein yield was higher in thrice-daily milked udder-halves $(P<0.01)$.

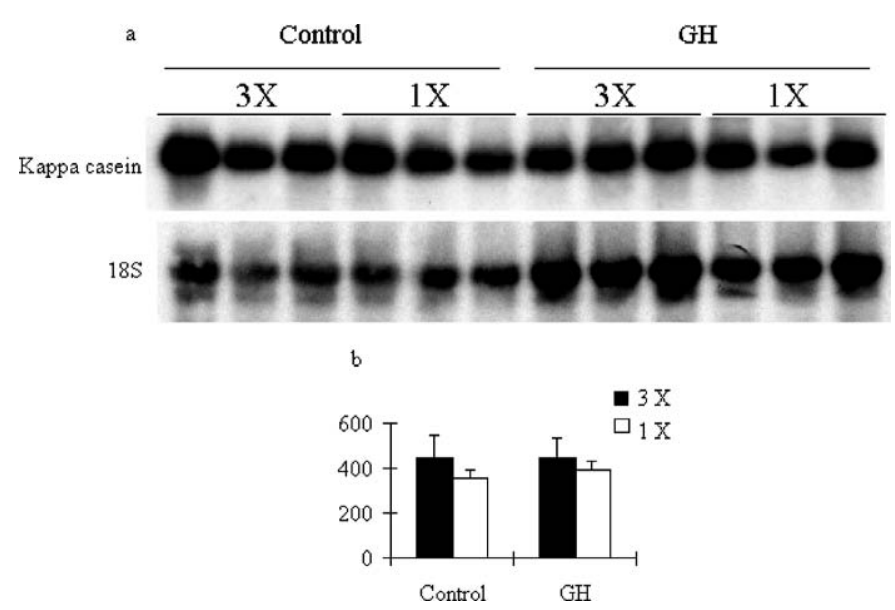

Figure 4. Kappa casein gene expression in udder-halves milked once $(1 \times)$ vs. thrice $(3 \times)$ daily in control vs. GH-treated goats $(n=6)$ after $23 \mathrm{~d}$ of treatment. Northern blot (a) was performed with a gel containing $10 \mu \mathrm{g}$ of total RNA. Membranes were hybridized with ${ }^{32} \mathrm{P}$ labeled kappa casein and 18S cDNA probes. Amounts of kappa casein mRNA (b) were quantified and expressed as a ratio of $18 \mathrm{~S}$ mRNA amount. 

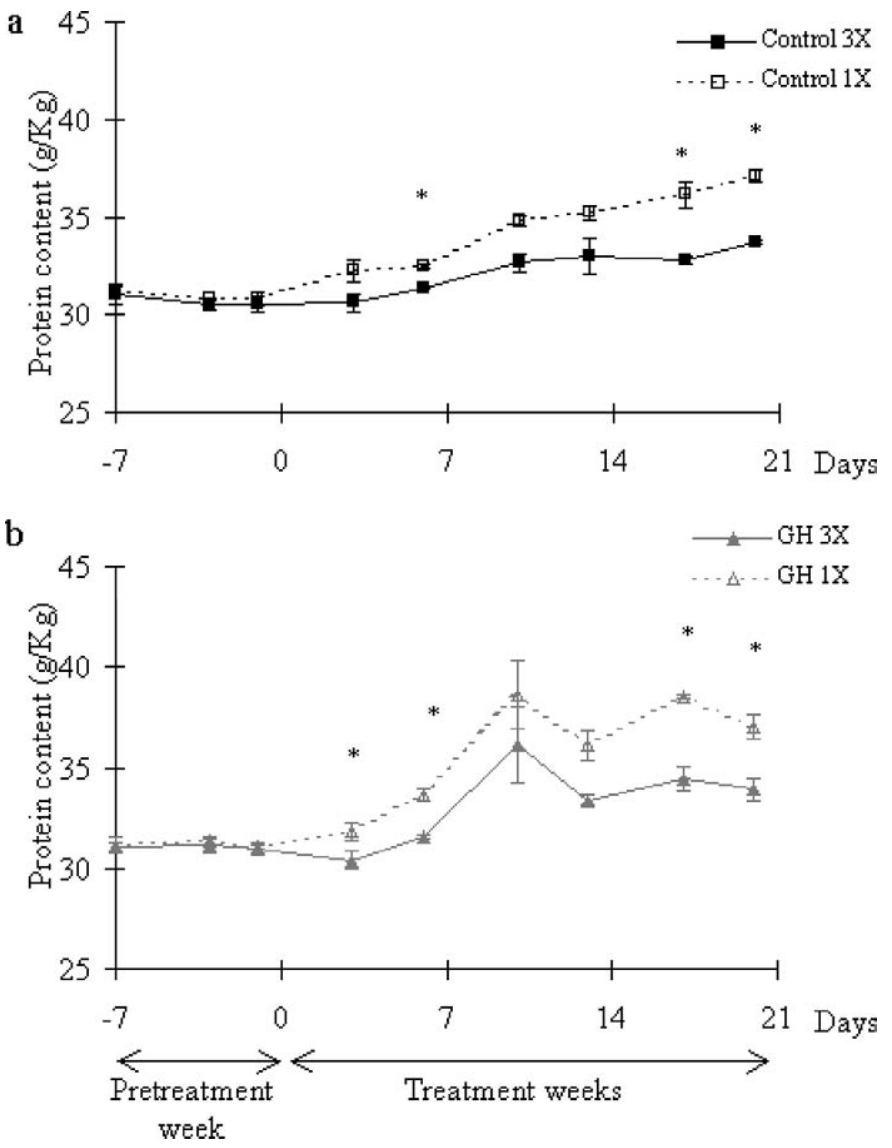

Figure 5. Milk protein content in udder-halves milked once $(1 \times)$ vs. thrice $(3 \times)$ daily in control (a) vs. GH-treated (b) goats during pretreatment weeks and $23 \mathrm{~d}$ of treatment. Mean values \pm SEM. Differences between $1 \times$ vs. $3 \times$ milk protein concentrations were assessed by Student's $t$-test $(*)$.

The significantly $(P<0.01)$ higher protein content in the milk from the once-daily milked udders was partly due to higher casein content $(P<0.03)$ and moreover to greater noncasein protein content $(P<0.01)$ as shown by the significantly $(P<0.03)$ greater casein:whey protein ratio for once-daily milked udder-halves (Table 3). Throughout the treatment weeks, an increase in protein content was also observed in GH-treated goats $(P<0.05, t$-test) with more abrupt changes than control goats (Figure 5). At d 9 , protein content in GH-treated goats was significantly higher than in control goats (Figure $5, P<0.05, t$-test). In the milk of the once-daily milked udder-halves, $\mathrm{GH}$ increased milk protein content (Table $3, \mathrm{~d} 12, P<0.05$ ) as well as whey protein content $(\mathrm{d} 12, P<0.05)$ with no effect on casein content; resulting in a lower casein:whey protein ratio (d 12, $P<0.05$ ). The specific effect of $\mathrm{GH}$ on whey protein content resulted in the loss of the correlation between protein concentration and whey protein concentration observed in control goats $\left(\mathrm{R}^{2}=0.67, P<0.001\right.$ and $\mathrm{R}^{2}=0.13$, NS in control vs. GH-treated goats; respec-

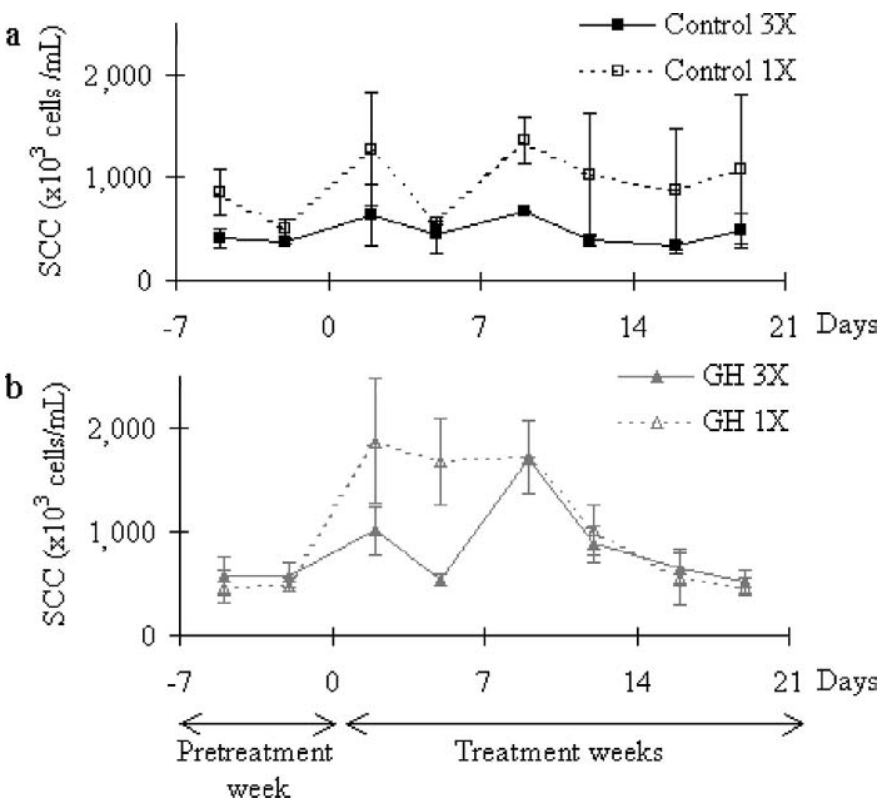

Figure 6. Somatic cell count in milk from udder-halves milked once $(1 \times)$ vs. thrice $(3 \times)$ daily in control (a) vs. GH-treated (b) goats during one pretreatment week and $23 \mathrm{~d}$ of treatment. Mean values \pm SEM.

tively, $\mathrm{n}=12$ ). During the last week of treatment, no significant difference was observed between control vs. GH-treated goats.

Mineral concentrations. In order to confirm the hypothesis according to which epithelium permeability is modified, mineral concentration in milk was measured to provide evidence of the state of the tight junctions. $\mathrm{Na}^{+}$ concentration in milk was higher in once-daily milked udders at $\mathrm{d} 19$ and 24 whereas $\mathrm{K}^{+}$concentration was not significantly affected by the treatment. Thus, a significantly higher $\mathrm{Na}^{+}: \mathrm{K}^{+}$ratio in the milk of once-daily milked udder-halves was observed (Table 4). In the milk of once-daily milked udder-halves, GH significantly increased the $\mathrm{Na}^{+}: \mathrm{K}^{+}$ratio at $\mathrm{d} 19$ and $24(P<0.05)$.

Somatic cell count. Even though the goats were free from intramammary infection, SCC showed changes related to the modification of the permeability of the mammary epithelium. Throughout the treatment weeks in control goats, SCC tended $(P<0.10, t$-test $)$ to increase in once-daily milked udder-halves, whereas it remained stable in thrice-daily milked udder-halves (Figure 6). As for protein content, during the treatment weeks, SCC in the milk of GH-treated goats increased $(P<0.05$, d 5 ; paired $t$-test) in once-daily milked udder-halves first. Then, at $\mathrm{d} 9$ of treatment, a similar increase was observed in the milk of thrice-daily milked udder-halves $(P<0.05$, $\mathrm{d} 9$; paired $t$-test). The magnitude of the increase in SCC tended to be higher $(P<0.10, t$-test $)$ in $\mathrm{GH}$-treated goats 
than in control goats. After $17 \mathrm{~d}$ of treatment, SCC was back to pretreatment values.

\section{DISCUSSION}

This study was performed to evaluate the mechanism of milk production induced by $\mathrm{GH}$, in comparison with the effects of differential milking frequency. Frequent milking increased milk yield in the same proportion as previously reported in goats (Henderson et al., 1985; Wilde et al., 1987; Knight et al., 1990) and GH treatment induced an additional increase in milk yield as reported by Knight et al. (1990). Reducing milking frequency to once-daily milking decreased milk yield in the same extent as previously reported (Wilde and Knight, 1990; Li et al., 1999), but GH failed to compensate for the negative effect of once-daily milking.

As shown by the relationships between milk yield and mammary gland weight and between milk yield and DNA concentration and total DNA content in control goats, milking frequency directly affected the number of mammary cells able to secrete milk. Histological analyses revealed that the variation in mammary cell numbers was in part due to variation in epithelial cell numbers inside the alveolus. Frequent milking or frequent suckling have been previously reported to increase the mammary gland weight (Henderson et al., 1985; Wilde et al., 1987), the DNA concentration (Tucker, 1966), the cell longevity (Wilde et al., 1987) and the rate of DNA synthesis associated with a stimulation of epithelial cell numbers (Hillerton et al., 1990). Thus, increasing milking frequency induced cell proliferation. In contrast, our results showed that reducing milking frequency induced a decrease in alveolar diameters. This is consistent with a loss of mammary tissue due to the induction of mammary cell apoptosis previously observed in goats ( $\mathrm{Li}$ et al., 1999). The relationship between milk yield and mammary gland weight and total DNA content confirmed the general idea that the number of cells is a major factor in milk production as previously reported in goats (Knight et al., 1990). A correlation between DNA at 60 $\mathrm{d}$ of lactation and milk production was also observed in cows (Tucker et al., 1973). However, this is the first time that this relationship has been shown by differential milking frequency.

In our study, GH induced a higher mammary glandular weight in all udder-halves with additional weight observed in udder-halves milked thrice daily. GH treatment affected the relationship between mammary gland weight and milk yield. The overall mammary weight induced by GH was less efficient for milk production per unit of weight. Moreover, GH did not affect the number of epithelial cells per alveolus as frequent milking. These results could suggest that GH affected another mam- mary component than secretory cells. The potential increase in mammary gland weight induced by GH could be associated with an increase in blood component since it has been reported that GH enhances mammary blood flow (Mepham et al., 1984).

It has already been shown that GH induced a higher mammary weight (Capuco et al., 1989; Kahl et al., 1995; Baldi et al., 2002) without modifying either DNA concentration over time, or thymidine incorporation (Knight et al., 1990), thus suggesting that cell hypertrophy could occur. A recent study showed a significant effect of GH on total DNA content in mammary gland of late lactating goats associated with maintenance of lactating alveoli (Baldi et al., 2002). In thrice-daily milked udder- halves, GH induced a decrease in DNA concentration, suggesting epithelial cell hypertrophy with a concomitant tendency of a higher total DNA content. Moreover, the relationship between milk yield and total DNA content was similar in control and GH treated-goats for three daily milkings, indicating that the stimulation in milk yield by $\mathrm{GH}$ in thrice-daily milked udder-halves was due to a higher cell number. In once-daily milked udder-halves, GH increased DNA concentration and tended to increase total DNA concentration. Thus, GH could limit the natural loss of secretory cell in late lactating gland and also limit the effect of reduced milking frequency on the loss of mammary epithelial cells. Considering the number of goats in this study, it was not possible to establish a significant effect of GH on total DNA content. Nevertheless, the overall stimulating effect of GH on cell number could result from stimulation of proliferation as recently observed in cows (Capuco et al., 2001) and/or from limitation of cell loss as suggested in goat (Baldi et al., 2002) and described in rats (Travers et al., 1996).

Beside cell number, treatments could interact to affect cell activity in the mammary gland. RNA concentration used as an indicator of the overall transcriptional activity, and expression of kappa casein gene was unchanged with the different udder-halves at the end of the treatment. These results are in accordance with a previous report in which no variation in the expression of several mammary genes (alpha $\mathrm{S} 1$ and beta casein, alpha lactalbumin) occurred associated with milking frequency in goats (Bryson et al., 1993). Local increase in milk yield was not accompanied by a change in specific mRNA levels and acute regulation of milk secretion may occur at a posttranscriptional level. Therefore, changes in mammary cell activity have often been measured by changes in the activity of several key mammary enzymes, such as acetyl CoA carboxylase, fatty acid synthetase, and galactosyltransferase. Increased enzyme activities were observed with frequent milking (Wilde et al., 1987; Travers and Barber, 1993). A significant decrease in mammary enzymatic activity was observed with infrequent 
milking (Wilde and Knight, 1990; Farr et al., 1995). Stelwagen proposed that mammary gland adaptation after milking frequency variation is time dependent. A relatively short treatment period of altered milking frequency is likely to modify cell activity, whereas longterm effects will relate to changes in cell number.

In this study, GH failed to increase total RNA content and kappa casein gene expression. In a previous experiment, we reported a relatively transient stimulation of the gene expression of three milk proteins, including kappa casein in the first week of GH treatment (Boutinaud et al., 2002). After $23 \mathrm{~d}$ of treatment, the increase in milk yield induced by GH seemed independent of milk protein gene expression. Under our experimental conditions, GH treatment failed to counteract the decrease in milk yield induced by once-daily milking. In cows, a compensatory effect of GH in association with infrequent milking has been reported. GH was able to reverse the decrease in milk yield by more than $10 \%$ (Carruthers et al., 1991) or to exceed the loss of milk yield (Stelwagen et al., 1994a). Nevertheless, our experimental design differed from other designs applied in cows where GH treatment was assessed 1 wk after the onset of infrequent milking. Moreover a species-specific responsiveness to GH could explain a less extended response in goats. The cisternal capacity has been thought to be a factor affecting the regulation of milk production during once-daily milking (Knight et al., 1994). It has been demonstrated in goats that the quantity of milk drained during $24 \mathrm{~h}$ was greater than the quantity of milk stored in the gland after $24 \mathrm{~h}$ (Stelwagen et al., 1996). Thus, the volume of milk storage after $24 \mathrm{~h}$ accumulation could physically prevent the galactopoietic effect of GH. In addition, the presence of feedback inhibitor of lactation (Wilde et al., 1998) in the alveolar lumina could inhibit the secretion of milk. Moreover, the accumulation of milk during 24 $\mathrm{h}$ could increase mammary pressure. It has been demonstrated that high intramammary pressure induced a decrease in mammary blood flow (Pearl et al., 1973) and could thus limit the action of GH on mammary blood flow. Furthermore, the association of mammary pressure induced by a $24 \mathrm{~h}$ of milk accumulation and mammary blood flow induced by GH could negatively interact on milk production by affecting the structure of the epithelium and consequently its permeability. Milking frequency was shown to affect tight junction closure in goats (Stelwagen et al., 1994b). In our experiment, several indices evidenced the variation of tight junction opening. Usually, the mineral balance between both compartments is prevented by the presence of tight junctions. The increase in $\mathrm{Na}^{+}$in milk and in the $\mathrm{Na}^{+}: \mathrm{K}^{+}$ratio is a signal of tight junction opening. In accordance with previous reports (Stelwagen et al., 1994b, 1997), we here report a higher $\mathrm{Na}^{+}: \mathrm{K}^{+}$ratio in the milk from once-daily milked udders. GH treatments transiently accentuated the effects of once-daily milkings on mineral concentration. The significantly higher protein content in the milk of once-daily milked udder-halves was mainly due to higher whey protein content as previously reported in cows (Lynch et al., 1991; Auldust and Prosser, 1998). Higher whey protein content in the milk of once-daily milked udders suggested a specific leakage of serum protein into milk after modification of the permeability of the mammary epithelium. Observations showed that the lowest values for the casein:whey protein ratios were obtained from once-daily milked udder-halves of GHtreated goats.

In many reports (Lynch et al., 1991; Stelwagen and Lacy-Hulbert, 1996; Kelly et al., 1998), once-daily milking increased SCC in milk, and as milk ouput decreased, cells were more concentrated (Kamote et al., 1994). However, in a recent study it was reported that an increase in polymorphonuclear cells appeared in milk (Kelly et al., 1998) by infiltration from blood due to the opening of tight junctions in once-daily milked glands. In control goats, a transient increase in SCC in once-daily milked udders and no variation in thrice-daily milked udders were reported, which is not in accordance with a concentration effect. It seems that an increase in tight junction opening better explains the variation of SCC. In GHtreated goats, the increase in SCC is well above that of control goats.

During differential milking frequency and GH treatment, the variation in milk composition may serve as further evidence of the opening of tight junctions in oncedaily milked udder-halves in which was observed higher $\mathrm{Na}^{+}: \mathrm{K}^{+}$ratios, higher protein content with a lower casein:whey protein ratios, and higher SCC. All these indicators suggested that epithelium permeability was affected. GH amplified the effect of once-daily milking on mammary epithelium. It has been demonstrated that tight junction opening in the mammary epithelium in vivo was associated with a decrease in milk yield (Neville and Peaker, 1981; Stelwagen et al., 1995). In cows, GH was able to reverse the decrease in milk yield induced by once-daily milking. Even though GH treatment resulted in a nonsignificantly greater SCC (Stelwagen et al., 1994a) or a higher protein content (Carruthers et al., 1991), it did not seem to affect epithelium permeability. In our experimental design in goats, the effects on the epithelium permeability may be responsible of the lack of compensatory effect of GH.

The opening of tight junctions in the case of once-daily milking could result from an inflammatory response due to the accumulation of milk in the cistern. It was observed that milk from distended udders of ewes exhibited more inflammatory activity (Colditz, 1988). Growth hormone has been reported to enhance neutrophil function and 
thus promote inflammation (Burvenich et al., 1999). In addition, even though SCC in cows is mostly not affected by treatment with GH, some data indicates a dose-related trend for increasing SCC with GH (Mc Clary et al., 1991). We hypothesized that GH treatment enhances the relatively slight inflammation induced by once-daily milking, thus preventing the increase in milk yield. Moreover, the inflammation of one udder-half seemed to be transmitted to the other udder-half as previously observed in cow (Guidry et al., 1983). Milk composition of thrice-daily milked udder-halves evolved similarly to that of once-daily milked udder-halves with a 3-d delay. Finally, the GH effect observed in thrice-daily milked udder-halves was only observed after $10 \mathrm{~d}$, confirming that a phenomenon, which could be an inflammation, induced a resistance against $\mathrm{GH}$ action (Boisclair et al., 2000; Johnson et al., 2001) and prevented the increase in milk yield at the beginning of the treatment.

\section{CONCLUSION}

Milking frequency and GH appear to affect different mechanisms involved in milk production. Milking frequency affected epithelial cell number and alveolar diameter without modifying cell activity. Growth hormone induced an additional increase in milk yield and mammary growth resulting from a potential epithelial cell hypertrophy in udder-halves milked thrice-daily and cell number maintenance in both udder-halves. These results provide evidence that GH could affect the balance between secretory cell and dead cell numbers. Milking oncedaily influences milk composition by affecting the epithelial permeability of the mammary gland. In the presence of GH, the tight junction opening was increased, which might have led to delaying the galactopoetic effects of GH in both udder-halves.

\section{ACKNOWLEDGMENTS}

The authors wish to thank Christine Leroux for the gift of kappa casein cDNA, Sandra Letort and Nicole Huchet (UMRPL, INRA St Gilles, France) for mineral and noncasein determinations in milk, and the INRA staff of the experimental farm of Brouëssy with a special mention to Damien for taking care of the animals.

\section{REFERENCES}

Amos, H. E., T. Kiser, and M. Loewenstein. 1985. Influence of milking frequency on productive and reproductive efficiencies of dairy cows. J. Dairy Sci. 68:732-739.

Auldist, M. J., and C. G. Prosser. 1998. Differential effects of short term one-daily milking on milk yield, milk composition and concentrations of selected blood metabolites in cows with high or low pasture intake. Proc. N.Z. Soc. Anim. Prod. 58:41-43.

Baldi, A., S. Modina, F. Cheli, F. Gandolfi, L. Pinotti, L. B. Scesi, F. Fantuz, and V. Dell'Orto V. 2002. Bovine somatotropin administra- tion to dairy goats in late lactation: Effects on mammary gland function, composition and morphology. J. Dairy Sci. 85:1093-1012.

Boisclair, Y. R., J. Wang, J. Shi, K. R. Hurst, and G. T. Ooi. 2000. Role of the suppressor of cytokine signaling-3 in mediating the inhibitory effects of interleukin-1 beta on the growth hormone-dependent transcription of the acid-labile subunit gene in liver cells. J. Biol. Chem. 275:3841-3847.

Boutinaud, M., H. Rulquin, D. H. Keisler, J. Djiane, and H. Jammes. 2002. Use of somatic cells from goat milk for dynamic studies of gene expression in the mammary gland. J. Anim. Sci. 80:1258-1269.

Bryson, J. M., C. J. Wilde, and C. V. Addey. 1993. Effect of unilateral changes in milking frequency on mammary mRNA concentrations in the lactating goat. Biochem. Soc. Trans. 21:294S.

Burvenich, C., M. J. Paape, D. Hoeben, H. Dosogne, A. M. Massartleen, and J. Blum. 1999. Modulation of the inflammatory reaction and neutrophil defense of the bovine lactating mammary gland by growth hormone. Domest. Anim. Endocrinol. 17:149-159.

Campos, M. S., C. J. Wilcox, H. H. Head, D. W. Webb, and J. Hayen. 1994. Effects on production of milking three times daily on first lactation Holsteins and Jerseys in Florida. J. Dairy Sci. 77:770-773.

Capuco, A. V., J. E. Keys, and J. J. Smith. 1989. Somatotrophin increases thyroxine- $5^{\prime}$-monodeiodinase activity in lactating mammary tissue of the cow. J. Endocrinol. 121:205-211.

Capuco, A. V., D. L. Wood, R. Baldwin, K. McLeod, and M. J. Paape. 2001. Mammary cell number, proliferation, and apoptosis during a bovine lactation: Relation to milk production and effect of bST. J. Dairy Sci. 84:2177-2187.

Carruthers, V. S., S. R. Davis, and D. H. Norton. 1991. The effect of oxytocine and bovine somatotropin on production of cows milked once a day. Proc. N.Z. Soc. Anim. Prod. 51:197-201.

Colditz, I. G. 1988. Studies on the inflammatory response during involution of the ovine mammary gland. Q. J. Exp. Physiol. 73:363-368.

Disenhaus, C., H. Jammes, J. Hervieu. F. Ternois, and D. Sauvant. 1995. Effects of recombinant bovine somatotropin on gaot milk yield, composition and plasma metabolites. Small Ruminant Res. 15:139-148.

Farr, V. C., K. Stelwagen, M. A. Kerr, S. R. Davis, and S. J. Eichler. 1995. Effect of once daily milking (ODM) on enzyme activities in the bovine mammary gland. Proc. N.Z. Soc. Anim. Prod. 55:12-13.

Guidry, A. J., M. Ost, I. H. Mather, W. E. Shainline, and B. T. Weinland. 1983. Sequential response of milk leukocytes, albumin, immunoglobulins, monovalent ions, citrate, and lactose in cows given infusions of Escherichia coli endotoxin into the mammary gland. Am. J. Vet. Res. 44:2262-2267.

Henderson, A. J., D. R. Blatchford, and M. Peaker. 1985. The effects of long-term thrice-daily milking on milk secretion in the goat: Evidence for mammary growth. Q. J. Exp. Physiol. 70:557-565.

Hillerton, J. E., C. H. Knight, A. Turvery, S. D. Wheatley, and C. J. Wilde. 1990. Milk yield and mammary function in dairy cows milked four times daily. J. Dairy Res. 57:285-294.

Johnson, T. S., M. O'Leary, S. K. Justice, M. Maamra, S. H. ZarkeshEsfahani, R. Furlanetto, V. R. Preedy, C. J. Hinds, A. M. El Nahas, and R. J. Ross. 2001. Differential expression of suppressors of cytokine signalling genes in response to nutrition and growth hormone in the septic rat. J. Endocrinol. 169:409-415.

Kahl, S., A. V. Capuco, M. Binelli, W. K. Vanderkooi, H. A. Tucker, and W. M. Moseley. 1995. Comparison of growth hormone-releasing factor and somatotropin: thyroid status of lactating, primiparous cows. J. Dairy Sci. 78:2150-2158.

Kamote, H. I., C. W. Holmes, D. D. S. Mackenzie, R. J. Holdaway, and B. W. Wickman. 1994. Effect of once daily milking in later lactation on cows with low or high initial somatic cell counts. Proc. N.Z. Soc. Anim. Prod. 54:285-287.

Kelly, A. L., S. Reid, P. Joyce, W. J. Meaney, and J. Foley. 1998. Effect of decreased milking frequency of cows in late lactation on milk somatic cell count, polymorphonuclear leucocyte numbers, composition and proteolytic activity. J. Dairy Res. 65:365-373.

Knight, C. H., P. A. Fowler, and C. J. Wilde. 1990. Galactopoietic and mammogenic effects of long-term treatment with bovine growth hormone and thrice daily milking in goats. J. Endocrinol. 127:129-138. 
Knight, C. H. 1992. Milk yield responses to sequential treatments with recombinant bovine somatotropin and frequent milking in lactating goats. J. Dairy Res. 59:115-122.

Knight, C. H., and R. J. Dewhurst. 1994. Once daily milking of dairy cows: Relationship between yield loss and cisternal milk storage. J. Dairy Res. 61:441-449.

Labarca, C., and K. Paigen. 1980. A simple, rapid, and sensitive DNA assay procedure. Anal. Biochem. 102:344-352.

Li, P., P. S. Rudland, D. G. Fernig. L. M. Finch, and C. J. Wilde. 1999. Modulation of mammary development and programmed cell death by the frequency of milk removal in lactating goats. J. Physiol. 519(3):885-900.

Lynch, G. A., M. E. Hunt, and D. D. S. Mackenzie. 1991. The effects of once daily milking as a practice in late lactation. Proc. N.Z. Soc. Anim. Prod. 51:191-195.

McClary, D. G., H. B. Green, R. P. Basson, and S. C. Nickerson. 1994. The effects of a sustained-release recombinant bovine somatotropin (somidobove) on udder health for a full lactation. J. Dairy Sci. 77:2261-2271.

Mepham, T. B., S. E. Lawrence, A. R. Peters, and I. C. Hart. 1984. Effects of exogenous growth hormone on mammary function in lactating goats. Horm. Metab. Res. 16:248-253.

Neville, M. C., and M. Peaker. 1981. Ionized calcium in milk and the integrity of the mammary epithelium in the goat. J. Physiol. 313:561-570.

Nielsen, M. O. 1988. Effect of recombinantly derivated bovine somatotropin on mammary gland synthetic capacity in lactating goats. J. Anim. Physiol. A 59:263-272.

Oman, D. S., and E. Seiden. 1988. Switch-back designs. Biometrika 75:81-89.

Pearl, S. L., H. F. Downey, and T. L. Lepper. 1973. Intramammary pressure and mammary blood flow in lactating goats. J. Dairy Sci. 56:1319-1323.

Puissant, C., and L. M. Houdebine. 1990. An improvement of the singlestep method of RNA isolation by acid guanidinium thiocyanatephenol-chloroform extraction. Biotechniques 8:148-149.

Raynal, F., B. Michot, and J. P. Bachellerie. 1984. Complete nucleotide sequence of mouse $18 \mathrm{~S}$ rRNA gene: comparison with other available homologs. FEBS Lett. 167:263-268.

Stelwagen, K., S. R. Davis, V. C. Farr, S. J. Eichler, and I. Politis. 1994a. Effect of once daily milking and concurrent somatotropin on mammary tight junction permeability and yield of cows. J. Dairy Sci. 77:2994-3001.

Stelwagen, K., S. R. Davis, V. C. Farr, C. G. Prosser, and R. A. Sherlock. 1994. Mammary epithelial cell tight junction integrity and mam- mary blood flow during an extended milking interval in goats. J. Dairy Sci. 77:426-432.

Stelwagen, K., V. C. Farr, S. R. Davis, and C. G. Prosser. 1995. EGTAinduced disruption of epithelial cell tight junctions in the lactating caprine mammary gland. Am. J. Physiol. 269:R848-855.

Stelwagen, K., C. H. Knight, V. C. Farr, S. R. Davis, C. G. Prosser, and T. B. McFadden. 1996. Continuous versus single drainage of milk from the bovine mammary gland during a 24 hour period. Exp. Physiol. 81:141-149.

Stelwagen, K., and S. J. Lacy-Hulbert. 1996. Effect of milking frequency in milk somatic cell count characteristics and mammary secretory cell damage in cows. Am. J. Vet. Res. 57:902-905.

Stelwagen, K., V. C. Farr, H. A. McFadden, C. G. Prosser, and S. R. Davis. 1997. Time course of milk accumulation-induced opening of mammary tight junctions, and blood clearance of milk components. Am. J. Physiol. 273:R379-386.

Stelwagen, K. 2001. Effect of milking frequency on mammary functioning and shape of the lactation curve. J. Dairy Sci. 84:E204-E211.

Travers, M. T., and M. C. Barber. 1993. Isolation of a goat acetyl-CoA caboxylase complementary DNA and effect of milking frequency on the expression of the acetyl-CoA carboxylase and fatty acid synthase genes in goat mammary gland. Comp. Biochem. Physiol. B 105:123-128.

Travers, M. T., M. C. Barber, E. Tonner, L. Quarrie, C. J. Wilde, and D. J. Flint. 1996. The role of prolactin and growth hormone in the regulation of casein gene expression and mammary cell survival: relationships to milk synthesis and secretion. Endocrinology 137:1530-1539.

Tucker, H. A. 1966. Regulation of mammary nucleic acid content by various suckling intensities. Am. J. Physiol. 210:1209-1214.

Tucker, H. A., J. A. Koprowski, and W. D. Oxender. 1973. Relationships among mammary nucleic acids, milk yield, serum prolactin, and growth hormone in heifers from 3 months of age to lactation. J. Dairy Sci. 56:184-188.

Wilde, C. J., A. J. Henderson, C. H. Knight, D. R. Blatchford, A. Faulkner, and R. G. Vernon. 1987. Effects of long-term thrice-daily milking on mammary enzyme activity, cell population and milk yield in the goat. J. Anim. Sci. 64:533-539.

Wilde, C. J., and C. H. Knight. 1990. Milk yield and mammary function in goats during and after once-daily milking. J. Dairy Res. $57: 441-447$.

Wilde, C. J., C. V. Addey, J. M. Bryson, L. M. Finch, C. H. Knight, and M. Peaker. 1998. Autocrine regulation of milk secretion. Biochem. Soc. Symp. 63:81-90. 